\title{
Building a Brand in Higher Education:
}

\section{A Review of the Literature on Higher Education Institutions Brand Management}

\author{
Sufrin Hannan* \\ Program Magister Management \\ Postgraduate School of Pakuan University \\ Bogor, Indonesia \\ *sufrinhannan@unpak.ac.id
}

\begin{abstract}
The challenges in University branding that have occurred are different from commercial branding related to issues of culture, branding concept, framework and brand architecture. This review aims to explore the nature of the brand management literature and how it can assist practitioners in higher education and researchers in the field of brand management in higher education institutions in generating and refining the reasons for the research undertaken. This paper has reviewed several things, such as the concept of branding in the context of higher education, marketing and commercialization, reputation management, and the importance of branding in the higher education sector. An attempt has been made to identify and integrate reasons into a consistent synthesis demonstrated by the use and impact of brand management on the brand value of higher education institutions for the long-term sustainability of higher education institutions.
\end{abstract}

Keywords-higher education institution (HEI), brand building, brand management, brand reputation management

\section{INTRODUCTION}

The globalization of higher education institutions has long been a policy for most universities and higher education in the world. This phenomenon of globalization of education is aimed at increasing connectivity between universities globally and combining it with economic, cultural and social change conditions [1]. However, changes that occur in higher education institutions are very complex and varied due to the unclear definition and concept of globalization in the field of education itself. Meanwhile, without realizing it, most universities have been directed by globalization. Universities that do not adjust will be excluded. Today, the flow of ideas, students, faculty and finance has flowed across borders and is supported by developments in information and communication technology that are changing the environment of higher education. This has implications for competition as well as collaboration between higher education institutions at home and abroad [2].

Currently higher education institutions need a market in a climate of international competition [3]. An exploratory study of various literatures and stated that challenges in university branding are different from commercial branding related to cultural issues, branding concepts, frameworks and brands architecture. These studies are conducted at UK Universities, but the same issues are found in many countries, meaning that the results can be compared internationally. Overall, the findings from this research provide a valuable contribution to our understanding of "the complexities of higher education branding" [4]. The fundamental change in the last 20 years in higher education is the increasing global competition in the higher education market and the consequence is that universities must adopt marketing practices including branding $[5,6]$. Many universities have to undertake embracing branding strategies. So, increasing competition between universities and higher education makes institutions need to understand, manage, and leverage a strong brand position $[7,8]$. Consequently, more and more universities apply common marketing techniques including brand management to compete effectively $[9,10]$.

The aim of this paper is to systematically build awareness regarding contemporary state of knowledge in the domain of brand management, especially how brand management in higher education is fit for brand management research. It is very crucial for this paper to document and analyze the latest research literature on brand management, starting from the scope of brand management in the Higher education sector, identifying gaps in the latest research literature and after that provide recommendations for future research areas.

\section{A. The Concept of Branding in The Context of Higher Education}

The American Marketing Association describes that a brand is a name, term, symbol, or design or a combination of the above items that can identify goods or services from one seller or group of sellers and differentiate them from competitors [11]. Brands have unique functional or emotional benefits and provide promise [12]. The Oxford Dictionary defines Brand as follows:... "Brand (noun): a particular make of good, and identifying trademark, label etc. An identified mark burned on livestock or former prisoners etc. with a hot iron, a piece of burning smoldering, or charred wood". In a more modern context, a brand can be defined as an asset that does not require a physical presence and its value cannot be 
obtained with certainty even though it has become the subject of specific business transactions such as buying and selling or acquisitions.

The branding concept can be seen here clearly demonstrating the concept of commercial acquiescence. Previous reviews or studies have also shown that there is no concurrence between the scholars on how a complete and holistic definition of the higher education brand should be and what its dimensions are. There is a difference between practitioner consensus and scholarships in the field of HEIs where HEIs concentrate more on their image in the market place. In essence, the institution's name or reputation determines its existence. At this time, the challenges of educational institution administrators are increasing in seeing market developments and in executing marketing strategies, especially their advertising programs to build a brand, because as usual the brand of higher education institutions has implications for the student admission process. Practitioners in the field of higher education branding and how it simultaneously impacts the brand value of the institution is needed. A higher education brand is a perception or emotion that is maintained by consumers or the perspective of consumers based on their experiences related to academic institutions $[13,14]$. Most of the literature on higher education branding focuses on awareness, taglines and mission statements only. A good brand in a higher education institution, however, requires a good opinion from external audiences in building the image of the institution and at the same time it is also considered a good image by internal audiences (such as faculty members, staff and student students) so as to create pride for the institution [15]. The brand of the university is a manifestation of the appearance of the institution and reflects the capacity of the institution to satisfy student needs, build trust and can help the institution in the recruitment process. When someone mentions the name of the University, the name will give associations, emotions and a good image [16].

\section{B. Brand management in Higher Education, Marketing and Commercialisation}

Each sector has its own challenges in building and maintaining a strong brand. The most important thing is to find unique and specific issues, including building a college brand. HEI, seen from the point of view of corporate brand issues, is closely related to brand management and growth in service organizations. As a non-profit organization, HEI marketing is a societal activity [17], and what is interesting is that the competitive market for postsecondary education has developed with multiple stakeholders [18-20]. HEIs are moving forward as a corporate model with very aggressive marketing [20-23]. As a higher education institution, HEIs are becoming increasingly marketized and promotional activities are increasing, which is very significant because brand building is very important [24-26].A strong brand for a university will make new students very attractive and this will also increase retention rates [27-29].
Higher Education is a service industry [10,30], and aspects of HEI branding that need to be considered are intangibility and inseparability [31]. HEI brands as a service brand require a great emphasis on internal marketing so that all employees will become consumer touch points and service brands play a role in reducing risks from the intangibility aspect [32,33]. Meanwhile, consumers show an expansion in the value of the HEI, because HEI brands are very essential to their social status [34]. Therefore, HEI must build a situation analysis process to create an effective position and strategy in presenting the image and reputation of HEI and building its position in the minds of the public $[35,36]$.

In the HEI area, early research on HEIs' in the context of marketization, has been carried out by Norman Fairclough [37,38]. In that context, marketing is more about directly sharpening the promotion function to students. It should be noted that it not only reflects HEI marketization developments, but also contributes to bringing about HEI developments and changes [38,39]. HE corporate branding and marketing discourse, this strategy represents and communicates idealized HEIs, as well as discursively constructs the organizations. The HEI branding activities are related to the expansion of the increasingly complex areas of education. Education and especially the academy have long been seen as a socio-didactic function that focuses on intellectual-moral cultivation and socialization [39-43]. HEI branding in the context of the marketing function of the organizations HEIs obtain similar didacticism which is conventionally associated with HEIs' educational roles, especially in contexts where education and corporations are facing increasing HEIs. More simply, in promoting an organization, HEI branding discourse, through tropes and the value of HEI as a branding encapsulates approach, can also contribute to 'teaching' audiences as values and priorities in HE [44]. Research from Fairclough's in the 1990 s on Market Orientation of HE systems in many parts of the world [45-48], and Singapore is no exception. The effort of HEIs in communicating HEIs in general also makes them more impressive, especially with the use of internet-based technology so as to accelerate and expand coverage. The provisions related to looking at prospectuses have a consequence that to carry out marketized HE at this time it is necessary to maximize the use of technological innovations such as the internet, WEB as an integrated marketing tool and branding, so that information is easily conveyed to anyone as stated by Graham regarding the diachronic study of UK university prospectuses notes [49]. Likewise, the case study at Scottish University shows how prospectus for institutions is one thing that makes student demand and is part of a focus on customer-driven organization to see the best university experiences in attracting consumers, in this case students [50]. So, there are 3 main approaches related to branding in higher education to make it acceptable to the market, including: (i) characterizing the brand; (ii) positioning the brand and (iii) personalizing the brand [51]. 


\section{Higher Education Brand Reputation Management}

Higher education institutions need to enter the market in a climate of international competition [10]. Branding requires a long process, with the aim of increasing brand knowledge, favorability and sales over time. A strong brand is a symbol of promise that it is not only related to the product being delivered but also to convey a certain type of experience to consumers when consumers use the brand. For HEI, the unique experience of HEI is a strength because the brand communicates a commitment to a certain experience. This is very critical for higher education, because it must ensure consistent performance according to consumer expectations [52]. Associated with an effective brand, the brand message must be credible and resonate with customers [11]. For example, FedEx has formed a brand as "the reliable provider of overnight shipping services. This brand message is trusted by consumers, benefiting both FedEx and customers. When properly managed, the brand will have a positive impact on the perceived value and actions of current and prospective customers. Thus, a strong institutional brand is the key to bringing consumers to a long-term relationship and a global competitive environment in which HEIs operate. A strong institutional brand is also the key to a strong customer relationship [53], and as was also stated by de Chernatony and McDonald [12], who claimed that the brand is an imperative relationship lubricant. Then, preferably, the brand should be a magnet for enhancing your relationship marketing effort. However, literature related to branding efforts by HEIs and subsequent effects in building customer relationships is still rare. Not much research has been done on how HE brands can become magnets for additional marketing efforts. Although brand reputation management is not research-intensive in the context of the HE market, it is generally used as a brand value. Broadly speaking, the marketing literature and brand management literature show that brand reputation is a value in creating tools where brand reputation has a positive influence on organizational equity. Brand reputation is used as a tool to promise quality products and services to consumers. Brand reputation will support the idea that company reputation is used as a promise for good brand quality and good service levels as well [54].

\section{Challenge of Brand Building and The importance of branding in the Higher Education.}

Building and maintaining a brand in the HEI sector is very challenging. It is from the UK perspective that the brand presents some real challenges [55].The system in certain higher education, although in the USA is the same as in the UK in the acceptance of branding as a concept $[19,29,56]$.This is possibly because in the USA there are cultural differences between market values and traditional academic values around the past 10 years. Activities that focus on commercial aspects such as branding are inherently difficult for universities if there is no need to build relevant linking departments that do not have commercial objectives. Equally, articulating real differences is often a challenge [21]. Several branding models such as Keller [11], LePla and Parker's [57] Integrated Brand Model, De
Chernatony and McWilliam's [58] Brand Box, and Kapferer's [59] Brand Identity Prism argue that identifying clear brand principles is very important. However, this step is quite difficult for higher education institutions [60], especially in terms of stakeholder interests, internal organizations and differences in services provided. Harvard Business School, as an example of a strong educational brand, argues that the brand is strong because Harvard has a clear position in the minds of customers. They argue that other higher education institutions are different and Harvard has a unique position [61]. Based on The World University Rankings 2020, the Higher Education World University Rankings 2020 includes almost 1,400 universities across 92 countries, standing as the largest and most diverse university rankings ever to date. The University of Oxford leads the rankings in first place, California Institute of Technology in the second place, the University of Cambridge in the third, while Stanford University, Massachusetts Institute of Technology, Princeton, Harvard, Yale, The University of Chicago, and Imperial College London all appear in the top ten. [62]. The six rank of Best Universities in Indonesia according to International Rankings are University of Indonesia, Bogor Agricultural University, Brawijaya University, Institute of Technology Bandung, Universitas Gadjah Mada and Airlangga University [63].

\section{CONCLUSION}

Currently higher education institutions need a market in a climate of international competition. Increased competition between universities and higher education makes institutions need to understand, manage, and leverage a strong brand position. The challenges of university branding are different from commercial branding regarding cultural issues, branding concepts, frameworks and brands architecture.

By identifying and integrating 63 branding literature on Higher Education and a consistent synthesis showing that the use and influence of brand management in institutions will generate brand value for long-term sustainability for higher education institutions. Brands have unique functional or emotional benefits and deliver promise. A higher education brand is a perception or emotion that is maintained by consumers or the perspective of consumers based on their experiences with academic institutions. The brand of the University is a manifestation of the appearance of the institution and reflects the capacity of the institution to satisfy student needs, build trust and can assist the institution in the recruitment process. When someone mentions the name of the University, the name will give associations, emotions and a good image. As a higher education institution, HEIs are becoming increasingly marketized and promotional activities are increasing, which is very significant because brand building is very important. A strong brand for a university will make new students very attractive and this will also increase retention rates. Branding requires a long process, with the aim of increasing brand knowledge, favorability and sales over time. Broadly speaking, the marketing literature and brand management literature show that brand reputation is a value in 
creating tools where brand reputation has a positive influence on organizational equity. Brand reputation is used as a tool to promise quality products and services to consumers. Building and maintaining a brand in the HEI sector is very challenging. activities that focus on commercial aspects such as branding are inherently difficult for universities if there is no need to build relevant linking departments that have no commercial purpose. A strong educational brand, because it has a clear position in the minds of customers. A unique position is necessary.

\section{REFERENCES}

[1] OECD (2009). Globalization and Higher Education: What might the Future Bring? Programme on Institutional Management in Higher Education (www.oecd.org/edu/imhe).

[2] Erisher W, Obert H.H., and Frank G., 2014. Brand Reputation Management within the Higher Education Sector: A Review of the Literature on Higher Education Brand Reputation Management. International Research Journal of Marketing, 2(1):1-8.

[3] Hemsley-Brown, J., \& Goonawardana, S. (2007). Brand harmonization in the international higher education market. Journal of Business Research, 60(9), 942-948.

[4] Chapleo, C. (2015).Brands in Higher Education: Challenges an Potential Strategies.International Studies of Management and Organization, p. 1-23.

[5] Becher, T. and P.R. Trowler .2001. Academic Tribes and Territories: Intellectual Enquiry and the Cultures. Philadelphia, PA: SHRE and Open University Press.

[6] Jevons, C. 2006. "Universities: A Prime Example of Branding Gone Wrong". Journal of product and brand management 15 (7): 466-467.

[7] Celly, K. S., \& Knepper, B. (2010). The California State University: A case on branding the largest public university system in the US. International Journal of Nonprofit andVoluntary Sector Marketing, $15(2), 137-156$

[8] Maringe, F., \& Gibbs, P. (2009). Marketing higher education: Theory and practice. McGraw-Hill International.

[9] Chapleo, C. (2011). Branding a university: Adding real value or smoke and mirrors? In M. Molesworth, \& R. Scullion (Eds.), The marketisation of higher education and the student as consumer (pp. 101-114). London: Routledge.

[10] Hemsley-Brown, J., \& Oplatka, I. (2006). Universities in a competitive global marketplace: A systematic review of the literature on higher education marketing. International Journal of Public Sector Management, 19(4), 316-338.

[11] Keller, K. L. (2003). Strategic Brand Management: Building, Measuring and Managing Brand Equity. New Jersey: Pearson, Upper Saddle River.

[12] de Chernatony, L., \& McDonald, M. (2003). Creating Powerful Brands in Consumer Service and Industrial Markets, 3rd Ed, Oxford: Butterworth Heinemann.

[13] Beneke, J. H. (2011). Marketing the Institution to Prospective Students A review of Brand Management in Higher Education, International Journal of Business and Management, 6(1), 29-44.

[14] McNally, D., \& Speak, K. (2002). Be your Own Brand: A Breakthrough Formula for standing out of the Crowd. San Francisco, Berrett-Koehler Publishers Inc.

[15] Shampeny, R. (2003). Colleges turn attention to branding in competition for new business. The Business Review.

[16] Bennett, R and Ali Choudhury, R. 2007. Components of The University Brand : An Empirical Study in Melewar, TC (Ed). Intangible Economies: Brand Corporate Image, Identity and Reputation in the 21st Century, proceedings of the 3rd Annual Colloquium of the Academy of
Marketing's Brand Corporate Identity and Reputation SIG, Brunel University, 12 -13 September 2007.

[17] Kotler, P., \& Levy, S. (1969). Broadening the Concept of marketing. Journal of Marketing, 33, 10-15.

[18] Dill, D. (2003). Allowing the market to rule: The case of the United States. Higher Education Quarterly, 57(2), 136-157.

[19] Kotler, P., \& Fox, K. (1985). Strategic marketing for educational institutions. Englewood Cliffs, NJ: Prentice Hall.

[20] Ruch, R. (2001). Higher Ed, Inc.: The rise of the for-profit university. Baltimore and London: The Johns Hopkins University Press.

[21] Brookes, M. (2003). Higher education: Marketing in a quasi-commercia service industry. International Journal of Nonprofit and Voluntary Sector Marketing, 8(2),134-142.

[22] Geiger, R. (2004). Knowledge and money: Research universities and the paradox of the marketplace. Palo Alto, CA: Stanford University Press.

[23] Naude, P., \& Ivy, J. (1999). The marketing strategies of universities in the United Kingdom. The International Journal of Educational Management, 13(3), 126-134.

[24] Finder, A. (2005, August 11). To woo students, colleges choose names that sell. The New YorkTimes, p. 1.

[25] Morphew, C. (2001). A rose by any other name? Which colleges become universities. The Review of Higher Education, 25(2), 1-26.

[26] Toma, J., Dubrow, G., \& Hartley,M. (2005). The uses of institutiona culture: Strengthening andbuilding brand equity in higher education. ASHE Higher Education Report, 31(2), 1-105.

[27] Cobb, C. (2001). University of Oklahoma, Oklahoma, (UMI No 3006667). The concept ofbrand identity in relation to students' intent-topersist, (Doctoral dissertation)

[28] Nguyen, N., \& LeBlanc, G. (2001). Image and reputation of highe education institutions in students'retention decisions. International Journal of Educational Management, 15(6),303-311.

[29] Sevier, R. (2002). Building a brand that matters. Hiawatha, IA: Strategy Publishing.

[30] Mazzarol, T., \& Soutar, G. (1999). Sustainable competitive advantage for educational institutions:A suggested model. The International Journal of Educational Management,13(6), 287-300.

[31] Lowrie, A. (2007). Branding higher education: Equivalence and difference in developing identity.Journal of Business Research, 60(9), 990-999.

[32] Berry, L. (2000). Cultivating service brand equity. Journal of the Academy of Marketing Science,28(1), 128-137.

[33] De Chernatony, L., \& Segal-Horn, S. (2003). The criteria for successful service brands.European Journal of Marketing, 37(7/8), 1095-1118.

[34] Hamann, D., Williams, R., \& Omar, M. (2007). Branding strategy and consumer high-technologyproduct. The Journal of Product \& Brand Management, 16(2), 98-111.

[35] Ivy, J. (2001). Higher education institution image: A correspondence analysis approach. TheInternational Journal of Education Management, $15(6 / 7), 276-282$

[36] Sirkeci, I. (2011). Marketing the British Business School: Role of research reputation in businessschool choice as perceived by the research leaders. BMAF Magazine, 12, 33-45, TheHigher Education Academy.

[37] Fairclough, N. (1994). Conversationalization of public discourse and the authority of the consumer. InR. Keat, N. Whiteley, \& N. Abercrombie (Eds.), The authority of the consumer (pp. 253-268). London:Routledge.

[38] Fairclough, N. (1995). Critical discourse analysis. London: Longman.

[39] Fairclough, N. (2001). Language and power (2nd ed.). London: Longman.

[40] Kim, T. (2007). Old borrowings and new models of the university in East Asia. Globalisation, Societiesand Education, 5(1), 39-52. 
[41] O’Neill, J., \& Solomon, Y. (1996). Education, elitism and the market. In B. Brecher, P. Fleischmann, \& J.Halliday (Eds.), The university in a liberal State (pp. 82-95). Aldershot: Avebury.

[42] Readings, B. (1996). The university in ruins. Cambridge, MA: Harvard University Press.

[43] Wernick, A. (1991). Promotional culture. London: Sage.

[44] Ng, C.J.W. (2014). 'We offer unparalleled flexibility': Purveying conceptual values in higher educational.corporate branding. Discourse \& Communication, 8(4), 391-410.

[45] Brown, R. (2011). The march of the market. In M. Molesworth, R Scullion, \& E. Nixon (Eds.), The marketisationof higher education and the student as consumer (pp. 11-24). London: Routledge.

[46] Han, Z. (2014). The marketization of public discourse: The Chinese universities. Discourse \&Communication, 8(1), 85-103.

[47] Iwasaki, M. (2009). The deception of the 'idea of self-responsibility' and 'individualization': Neo-liberalrhetoric as revealed in the corporatization of Japan's national universities (trans. A. Moore). Inter-Asia Cultural Studies, 10(2), 248-259.

[48] Lin, A. (2009). Local interpretation of global management discourses in higher education in HongKong: Potential impact on academic culture. Inter-Asia Cultural Studies, 10(2), 260-274.

[49] Graham, C. (2013). Discourse of widening participation in the prospectus documents and websites ofsix English higher education institutions. British Journal of Sociology Education, 34(1), 76-93.

[50] Askehave, I. (2007). The impact of marketization on higher education genres - The internationalstudent prospectus as a case in point. Discourse Studies, 9(6), 723-742.

[51] Ng, C.J.W. (2016). Hottest brand, Coolest Pedagogy': Approaches to Corporate branding in Singapore's Higher Education Sector. Journal of Marketing for Higher Education, p. 1-23.
[52] Keller, K (2009). Building Strong Brand in modern Brand communications Environment, Journal of Marketing 15(2), 139 -155.

[53] Pulley, J (2003). Romancing the Brand. The Chronicle of Higher Education, 50(9), 30-32.

[54] Devine, I., \& Halpern, P (2001). Implicit Claims: The Role of Corporate Reputation in value creation. Corporate Reputation Review, 4(1) \, 42 51.

[55] Bodoh, J. and R. Mighall. 2003. "Study Here Because You're Worth It." The Times Higher Education Supplement March 7: 23.

[56] Johnston A. 2001.’Branding: the Key to Student Recruitment (or Maybe Not)." Education Marketing. March 2001: 28-29.

[57] Le Pla, F. J., and L.M. Parker. 2002. Integrated Branding. UK: Kogan Page.

[58] De Chernatony, L., and G. McWilliam. 1990. "Appreciating Brands as Assets through a Two -Dimensional Model." Journal of Marketing Management (9): 173-188.

[59] Kapferer, J. N. 1992. Strategic Brand Management. London: Kogan Page.

[60] Hankinson, G. 2001. "Location Branding: A Study of the Branding Practices of 12 English Cities." Journal of Brand Management 9(2): 127142.

[61] Dibb, S., and L. Simkin. 1993. "The Strength of Branding and Positioning in Services." International Journal of Service Industry Management 4 (1): 25-35.

[62] https://www.timeshighereducation.com/world-universityrankings/2020/worldranking\#!/page/0/length/25/sort_by/rank/sort_order/ asc/cols/stats

[63] https://www.mastersportal.com/ranking-country/109/indonesia.html. 